IJLRES - International Journal on Language, Research and Education Studies ISSN: 2580-6777 (p); 2580-6785 (e)

Vol. 1, No. 2, 2017

Page: 256 - 269

\title{
THE ROLE OF COMMUNICATION OF COMMUNITY FIGURE IN AFFECTING THE VOTERS' CHOICE IN THE ELECTION OF PEMATANGSIANTAR CITY, NORTH SUMATERA PROVINCE, 2016
}

\author{
Aswan Jaya \\ aswanjaya@gmail.com \\ School of Postgraduate, State Islamic University of North Sumatra \\ Katimin \\ katimin@uinsu.ac.id \\ State Islamic University of North Sumatra, Indonesia
}

\begin{abstract}
This study aims to explore the role of community leaders in influencing voter choice in Pematangsiantar City Head Election 2016. this research is a qualitative research with indication that every data in this research is expressed descriptively without using numbers and symbols. The research data is taken from interviews and direct case studies in the field by meeting community leaders and community members directly involved in the election of Pematang Siantar. The results showed that; 1). Community leaders who can influence voters' choice are those who have known the candidate partner for a long time and are close friends of the candidate pair. 2). Community leaders who can influence voters' choice are those who know only the Mayor or only the Vice Mayor. 3) Community leaders who can influence voters' choice are those who have worked with these candidates. as conclusion in this research can be explained that Pematangsiantar Pematangsiantar Pematangsiantar election is very influenced from elektabilitas Candidates against the People of Pematangsiantar City, so if the Candidates want to win this Pilkada then they must have a special closeness with community leaders there.
\end{abstract}

Key Words; The Role of Communication, Community Figure, Voters' Choice, Election

\section{INTRODUCTION}

The role of community figure is actually very significant in influencing the community to make their choice when the elections take place. This role will be heightened when community leaders are in an environment where voter political awareness is low due to low economic background, low education level and limited access to information. This is where community leaders have the potential to affect voters to vote for their desired candidates.

In the midst of the strong role of community figure in influencing voters' choice in the election process, the fact that many heads of regions are directly elected in cases of 
corruption and drugs, the existence of community leaders should be questioned again and must be reviewed / re-examined. Has this community leader previously made a selection on the candidate's profile for further submission to the community? What underlies community leaders to determine support for one of the candidates for the regional head? How do community leaders communicate to the public to influence voter choice in the direct election of the regional head? And to what extent did the communication of the public figure influence the society's choice?

The Pematangsiantar election included part of the implementation of direct elections simultaneously the first wave of the important agenda of the event of democracy in Indonesia. But it should be postponed, because there is a lawsuit made one of the candidate couples declared dead by KPUD Pematangsiantar City. Interestingly again, the candidates will be declared the deceased is the only candidate candidate where the candidate is a Muslim walikotanya.

Such a hot political situation, of course, drags various elements and figures of Islamic society into the whirlpool of political interest. At that moment, the role of community leaders worthy and worthy to be considered in order to defend and bring the aspirations of Muslims in Pematangsiantar City. Because that's why this study took the location Pematangsiantar City of North Sumatra.

\section{LITERATURE REVIEW}

\section{Islamic Communication}

The study of Islamic communication is fundamentally different from the general study of communications. Islamic communication is based on the Qur'an and the Hadith that uphold the truth, when public communication prefers political and material benefits. The difference in principle because the science of public communication views that communication and information as a commodity that is traded for the benefit of communicators. Because public communication embraces the ideology of free flow of ideas by word and image. Anyone is free to convey information as long as it is interesting, without having to be bound by the values prevailing in society. Meanwhile, the ideology of Islamic communication is essentially to realize the happiness of 
individuals and audiences. Communication is waged with a sense of responsibility and is limited by the values in a society. ${ }^{1}$

The science of Islamic communication is indeed a relatively new study, due to various unrest over philosophy, theoretical approach and the application of communication science developed in the West is not fully in accordance with Islamic religious and cultural values. Therefore, the desire to re-examine the science of communication with the approach and perspective of Islam. Apart from that, as an academic of Islam strongly believes that Allah Almighty who has taught humans to communicate, using the intellect and language skills that He bestowed on us.

\section{Islamic Communication Ethics}

In Islamic ethics commonly called by morals. Therefore communicate must meet the demands of morals as contained in the source of Islamic teachings themselves. For Muslims, good communication is communication in accordance with the values contained in the Qur'an and hadith. Thus the ethics of Islamic communication can be interpreted as good values and bad, inappropriate and inappropriate, useful and useless, and which can be done with that should not be done when conducting communication activities. The ethical values of Islamic communication are sourced from the source of Islamic teachings namely the Qur'an and hadith. In general, the ethical values of Islamic communication are:
a. Be honest
b. Maintains the accuracy of communication messages
c. Being constructive and responsible
d. Can provide constructive criticism.

\section{The Principles of Islamic Communication The Principle of Sincere}

A message will not have a positive impact on the communicant if accepted with a heart that is not sincere. Ikhlas is the work of the heart. Language, sincerely derived

\footnotetext{
${ }^{1}$ Syukur Kholil, Kata Pengantar dalam Dedi Syahputra, Komunikasi Politik...., p. v
} 
from the word khalasha which means holy, clean from the stain. ${ }^{2}$ The sincerity of the term means the work done by the heart to purify itself from various motives that are not true. Not sincerely conveying or receiving messages means not the sincere desire to convey or receive messages.

\section{The Principle of Honesty}

Oral can kill a person's character, can damage the relationship of husband and wife, the kin, and even can cause blood pertumbahan. Because of the oral, the community can fall apart. As the saying of the Messenger of Allaah: From Abdullah bin Amr said, Rasulullah SAW said: "There will be slander that makes Arabs die lying. Oral at that moment is much sharper than a sword"3

\section{The Principle of Cleaning}

Islam strongly emphasizes the principle of cleanliness in everything, including in conveying the message. A good message will bring psychological comfort to those who receive it, while sarcastic messages, dirty, bloody, quarrels, infidelity, sheep fighting, gossip, swearing and the like will have an impact on the clumsiness of the heart.

\section{The Principle of Positive}

Positive messages are very influential for a person's happiness in whatever condition he or she is. A communicator who often sends a positive message to the communicant will save a lot of capital to do a positive. From Anas bin Malik, in fact the Prophet is glad that he came out for a matter of listening to people who menguncapkan: may always be in guidance, may always be successful.4

\section{The Principle of Package (Heart, Tongue and the Action)}

Man is a creation created by God in a complete package. There are elements of the soul and there are elements of the body. The movement in the Islamic concept is strongly influenced by the heart or soul. That is, oral will speak good when his heart is

\footnotetext{
${ }^{2}$ Ibrahim Mustafa dkk, Al-Mu'jam al-Wasith, (Kairo: Dar al-Da'wah), p. 249

${ }^{3}$ Sunan al-Tarmidzi, Juz 4, Hadis No. 2178, p. 43

${ }^{4}$ Sunan al-Tarmidzi, Juz 3, Hadis No. 1616, h. 213. Dia berkata, Hadis ini hasan gharib sahih
} 
good, and oral will not be able to speak well and smoothly without control of his soul, which he pronounces will feel bland. Allah's Messenger (May peace be upon him) said: "... Know that there is a clot of flesh, if it is good, then all the body, and if it is broken, then the whole body is destroyed, that is the heart".$^{5}$

\section{The Principle Two Ear One Mouth}

Recounting all that is heard is a sign of one's carelessness. Not all information that comes to a person is properly understood or understood correctly but the message is incorrect, or the message is true but is not fit for public consumption. Recounting all that is heard will risk having a lot of error levels. In Islam is called sin. From Abu Hurayrah, the Prophet said: "It is enough sin for a person to communicate all that he has"

\section{The Principle of Supervision}

The principle of supervision arises from the believer's belief that Allah is allhearing, all-seeing and all-knowing. In addition, they also believe that every word spoken will be recorded angel recorder

\section{The Principle of Selectivity and Validity}

The principle of selectivity and validity in Islamic communication is not only aimed at giving satisfaction to communicants in this world, but their main goal is to be accountable for what they present when asked for accountability in the afterlife.

\section{Principles of Interplay}

As it is known that communication between humans is an activity of conveying and receiving messages from and to others. As communication progresses, the process of influence affects occurs. In addition, communication also aims to get to know each other, connect, play, help each other, share information, develop ideas, solve problems, increase productivity, generate morale, convince, entertain, establish status, sedate and

\footnotetext{
${ }^{5}$ Abu Zakariyya, Muhyiddin Yahya bin Syaraf al-Nawawi, al-Minhaj, Syarh Shahih Muslim bin al-Hajjaj, (Beirut: Dar Ihya al-Turats al-Arabi, 1392), Juz 11, Hadis No. 107, p 28
} 
create a means of unity. ${ }^{6}$ But communication between people can also be the opposite, influencing influence for something that can make people fall into oblivion.

\section{The Principle of News Balancing}

With this principle, the information we receive will be more accurate, since conflicting parties sometimes provide emotionally and sometimes exaggerated information. In writing the news is also known a term cover both side which means fair treatment of all parties who become news object or also called with a balanced coverage. We must present all relevant facts and perspectives of the issues being reported. We must be neutral and impartial.

\section{The Principle of Privacy}

Surely everyone has privacy and privacy that should not be disclosed to the public, as well as other organizations or institutions. Leaking the secret is the same as stripping people, organizations and other institutions and embarrassing them. Allah forbids believers from searching for information about problems that fall within the privacy space.

\section{METHODOLOGY}

This type of research is qualitative, ie research that is not done by using formulas and statistical symbols.7 This study also aims to explain the phenomenon in depth through data collection. So in this research more emphasized the problem into (quality) data, not amount (quantity) data. Referring to Strauss and Corbin qualitative research is a type of research that the discovery procedure does not use statistical or quantification procedures. In this case qualitative research is the study of one's life, story, behavior and also about organizational functions, social movements or mutual relations. ${ }^{8}$

The research approach is descriptive analysis. According to Issac and Michael as quoted by Jalaluddin Rahmat that a descriptive approach aims to describe

\footnotetext{
${ }^{6}$ Josep A. Devito, Human Communication, The Basic Course (New York, Harper Collins Publishers, 1991), p. 6

${ }^{7}$ Nawawi Hadari, Penelitian Terpadu, (Yogyakarta: Gajah Mada University Press, 1996) p. 46.

${ }^{8}$ Ibid, p 41.
} 
systematically the facts or characteristics of a particular population or field in a factual and accurate. In other words, a descriptive approach is a research method that sees object, systematic, factual and accurate description of the facts being investigated and the results can be used for future decision making. ${ }^{9}$ Descriptive approach also aims to get a detailed description of the words, writings, and behavior that can be observed from an individual community groups and organizations in a particular setting that is studied from a comprehensive point of view. ${ }^{10}$

\section{Data Sources}

As for the reference material for the completion of this research, there are two sources of data that become the reference of researchers, namely primary and secondary data sources. The primary data are:

1. The Community figure with the criterias as follows:

a. Moeslim

b. At the time this research was being held one of the public positions

c. Have a socioeconomic status higher than the average community

d. Involved in the process of winning one of the mayor of Pematangsiantar of North Sumatera Province in Pilkada in 2016

2. Community Members ;

a. Living in the same environment with community leaders (kelurahan-based).

b. Low level of education and economy so that can be categorized by ordinary people.

c. Have voting rights at the election of Mayor of Pematangsiantar of North Sumatera Province in Pilkada 2016.

While secondary data is complementary data or data that provide information or additional information to the researcher as a complementary material of research such as books, journals, mass media (print), brochures and socialization tools and campaigns

\footnotetext{
9 Jalaluddin Rahmat, Metode Penelitian Komunikasi Dilengkapi Contoh Analisis Statistik, (Bandung: Rermaja Rosdakarya, 1984), p. 22

${ }^{10}$ Rosyadi Ruslan, Metode Penelitian Publik Relation dan Komunikasi, (Jakarta: Raja Grafindo Persada, 2004), p. 213
} 
Candidate Mayor Pematangsiantar Sumatra North that supports the title of this research.

\section{The Technique of Collecting Data}

1. In-depth interviews with Islamic community leaders and community members in Pematangsiantar City, North Sumatera Province.

2. Study documentation; looking for data about things in the form of notes, transcripts, books, newspapers, magazines, minutes, and agenda. ${ }^{11}$

\section{The Technique of Data Analisys}

The model used in analyzing data is the interactive model of Huberman and Miles. This model mentions the existence of interactive nature between collective data or data collection with data analysis. Analysis of data in question is data reduction, data presentation and verification or withdrawal of conclusions. Reduction is to pattern data with a form of analysis that sharpens, categorizes and directs. By organizing the data it can easily present or describe the necessary data to be delivered in an inductive way. Thus it can be drawn with the conclusion / verification in analyzing the data of the research.

Picture. The Huberman dan Miles model of Interactive data Analysis ${ }^{12}$

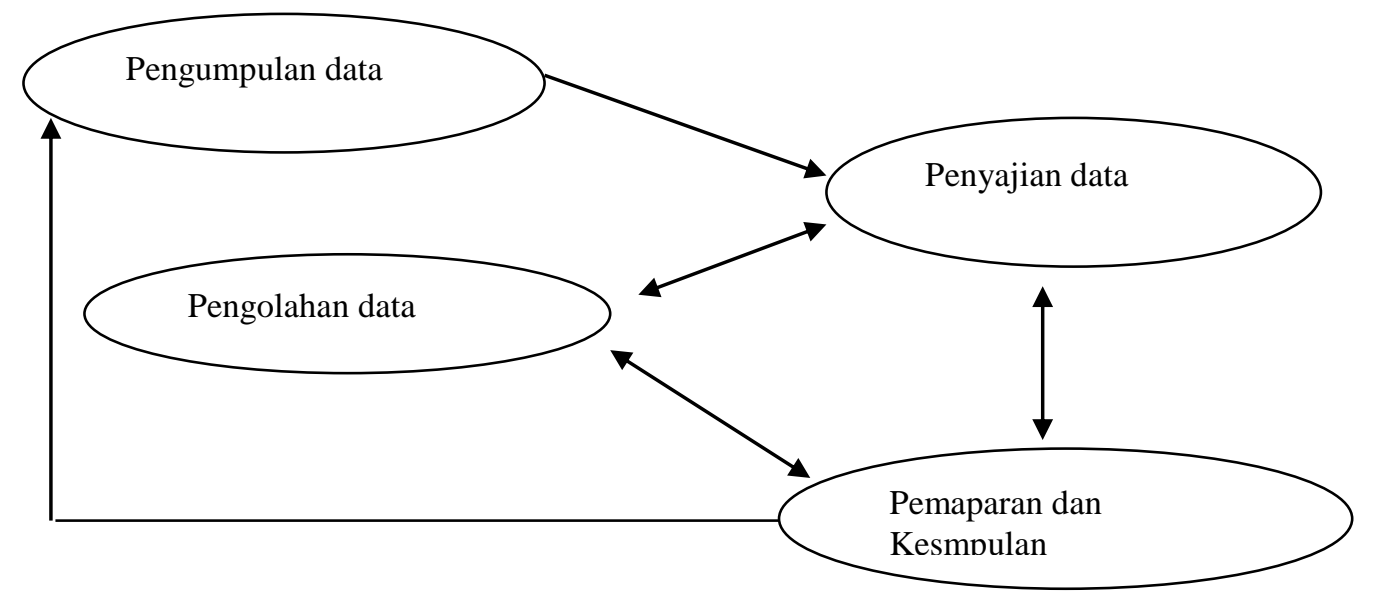

${ }^{11}$ Rosady Ruslan, Metode Penelitian; Public Relations dan Komunikasi, (Jakarta: RajaGrafindo Pers, 2008) p. 31. 247

${ }^{12}$ Sugiyono. Metode Penelitian Kualitatif, Kuantitatif Dan R\&D, (Alfabeta, Bandung, 2011), p 
The Role of Communication of Community Figure in Affecting the Voters' Choice In the Election of Pematangsiantar City, North Sumatera Province, 2016

\section{FINDINGS AND DISCUSSION}

\section{How Community Leaders Selected Candidates}

From the research process by using the instrument of interview to the informants that some of the Islamic community leaders in Pematangsiantar City about the selection process of candidates, it turns out the method and the Islamic guidance in the selection process of the candidates are no longer used. This is understandable because the situation is no longer possible to meet the principle. Nevertheless, the speakers continue to select the methods they have respectively subjectively. From the result of the subjectiv selection, it can be seen that the factors have known the candidates to be the foundation of the community leaders to choose the choice to support one candidate pair.

\section{a. Knowing the Candidate Pair}

The first factor of the selection process undertaken by community leaders in determining their support for one of the four candidates for Pemkasan Pemarsiantar Regional Head Election is that the community leaders from the beginning already knew the candidate pairs, both as candidates for the mayoral and vice-walikotanya. As expressed by Ustadzah Royani Harahap13, “antara saya dan calon jauh sebelumnya sudah saling kenal. Bahwa kami berteman lama. Sering bertemu baik secara formal maupun informal. Dalam setiap pertemuan kami sering berdiskusi untuk berbagai persoalan terutama keinginan untuk melakukan perubahan dari berbagai aspek di Kota Pematangsiantar". ("Between me and the candidate far before had known each other, that we were old friends. Often meet both formally and informally. In every meeting we often discuss for various issues especially the desire to make changes from various aspects in Pematangsiantar City ").

In contrast to Ustadzah Royani who kept his dukugannya secret, Ustadz Saiful Amin Lubis openly and bluntly stated to have dropped support to the candidate pair number 2, namely Hulman Sitorus and Hefriansyah. The fall of support to the candidate pair is very motivated by the introduction of a long and good. Even this introduction

\footnotetext{
${ }^{13}$ Royani Harahap, S.Ag, born on November 11, 1974, having his address at Singosari Street 18G P Siantar North Siantar Subdistrict, Martoba Village. Mother graduate of Religious Graduates is active in various Islamic organizations and pemudaan in Pematangsiantar City, such as that He is currently serving as Chairman of Fatayat NU, once as a leader in IPPNU, entered the board of DPD BKPRMI management, DMI board, during his student activity in various activities of PMII. Youth organized into the daily board of KNPI and jug, IPSM. The interview was conducted on November 9, 2016, at 10:30 pm
} 
took place long before Hulman Sitorus was elected as Mayor of Pematangsiantar in the direct Pilkada period, and when he was Mayor, their friendship continued to be well established. So it can be understood that support is given as a form of friendship "Kami sabagai sahabat memang harus saling mendukung" ("We as friends should support each other").

\section{b. Only knowing the Candidate of Vice Mayor}

The second factor of the selection process conducted by community leaders in determining their support for one of the four candidates Pematangsiantar Pemkont Pemarsiantar based on the figure of the vice mayor candidate. This is because they previously did not know the four prospective mayors who advanced in elections in 2016 this. As stated by the Ancient Boy Paradi who dropped support to the pair numbered 4; Wesly Silalahi and Sailanto, that he did not recognize closely any of the four would-be mayors who came forward and knew only close to his would-be deputy mayor. Of the four would-be deputy mayors, three of them are members of Parliament Pematansiantar City which is a profession and an office with Boy who is also a member of Parliament Pematangsinatar City. So it is reasonable and reasonable they know each other. Meanwhile, the process of recognizing the figure of his mayor candidate closely took place during the times of socialization and communication to the voters and it lasted very short, just no more than two months.

\section{c. Do not Know the Candidate Pair}

The third factor of the selection process of the candidates to be supported From the four pairs of candidates mayor Pematangsiantar actually outside of the grip that should be included in part of the selection process like the two things above. But what Ustadz Abdul Salam did not know all the candidate pairs, either the mayor candidate or the candidate's vice-walikotanya, did the selection through the socialization media and campaign (props) of all candidate pairs received from each successful team. The visual aids in the form of leaflets (brochures) he learned in such a way with the approach through the deepening of profiles of each candidate and adjustment of the program in 
The Role of Communication of Community Figure in Affecting the Voters' Choice In the Election of Pematangsiantar City, North Sumatera Province, 2016

accordance with its own interests. From the results of the selection, Ustadz Abdul Salam finally dropped support to the pair number 4 .

When referring to the two-stage communication model, the selection process conducted by Ustadz Abdul Salam corresponds to the model. This model explains that the message will reach the masses through two stages, the first stage as a process of mass communication; each pair of candidates publishes various props printed in bulk in the form of leaflets, brochures, and so forth, then spread to the public figures referred to in this model as the opinion leader.

\section{The Way of Community Figure Determines the Supporting}

From field observations and interviews that have been conducted by researchers to the informants found there are three important foundations on which the support is given. First; a foundation that is based on the programs offered by the candidate pairs. Figures who agree with the offer of the program given by the candidate pairs sehigga be the basis of its support is given Ustadz Yunan, Ustadz Albar Suheri and Ustadz Abdul Salam.

Second; the basis based on the assessment of the personality of the spouse or one of the candidate pairs and the candidate pairs is a representation of the representation of interests based on religion and tribe. Community leaders who dropped support with the foundation are Ustadzah Royani Harahap, Ustadz Saiful Amin Lubis, Ustadz Narimo, Ustadz Ki AH Mugiono, Ustadz Muhammad Gunario and Ustadz Subagio

Third; the basis of which is based on external factors or can be called incidental support. This foundation is not an ideal when measured in a scientific perspective, but the field facts find such a thing. Figures that provide support based on the foundation are Ustadz Hasanuddin Nasution, Ustadz Boy Paradi Purba and Ustadz Muhammad Rusli.

\section{Personality Assessment and Representation}

From the results of research that has been done, in addition to the similarity of vision and program in building Pematangsiantar City, there are factors that are also strong in influencing the support of community leaders to one of the candidate pairs, 
namely the assessment of the personality of one of the candidate pair performed by community leaders . Likewise, the assessment of the representation or representation of interests, tribes and religions also influence the support. This factor becomes a separate variable from the selection process of candidates conducted by community leaders, especially those who know more than one of the candidate pairs which then used as the foundation to support the candidate pair of Mayor and Deputy Mayor Pematangsiantar.

The above is evidenced by various statements from the public figures themselves, as expressed by Ustadzah Royani Harahap, "Personally I support the candidate has a pretty good personality, candidates are diligent in approaching and conducting various meetings with our party. In the program that we have the same vision of making changes from various aspects in order to build a better society ".14

\section{CONCLUSION}

In the end, the figures of the Islamic community are only served on four candidate pairs who actually have not represented the interests and passion of those who had previously thrived on the long-awaited hope. However, these community leaders must continue to elect and support one of the four pairs of candidates of Mayor and Deputy Mayor of Pematangsiantar. The process of making choices and how they communicate candidate pairs to gain support from the community is the focal point of this study with the following conclusions;

1. In the process of selecting candidate pairs, there are three main factors to be used as guidance for community leaders, firstly, on the basis that between community leaders and candidate pairs (mayors and vice mayors) have known each other. Secondly, on the basis that community leaders have known each other with the only vice-canoral candidate and third, did not know the previous candidate pair, so the choice was dropped on the basis of introduction through props (campaigns) that had spread.

2. Not enough just to know the candidate, community leaders also have a variety of important foundations as a basis to ensure support to one of the candidate pairs.

${ }^{14}$ Royani Harahap, S.Ag, Head of Fatayat NU, BKPRMI and DPD KNPI Pematangsiantar, interview: November 9, 2016 
The Role of Communication of Community Figure in Affecting the Voters' Choice In the Election of Pematangsiantar City, North Sumatera Province, 2016

The variety of foundations is summed up in, first, on the basis of the programs offered by the candidate pairs and is considered appropriate for the interests and aspirations of Muslims. Secondly, it is based on an assessment of personality and is a representation of representation of interests based on religion and ethnicity. Third, based on other factors, namely following orders from the central leadership of the organization and there is also a factor of forced due to the internal dynamics of the organization.

3. When the choice is established, all public figures disseminate political messages that are generally done with large and small group communication methods. In melakoni the role of communications, community leaders are grouped into two, first, groups of community leaders who are active in communicating within the internal organization or congregation and in the neighborhood where he lived. Second, groups of public figures who are not active in communicating to the internal organization or to the community at home.

4. The role of communication of public figures in influencing voter choice in Pematangsiantar Pemkong Pemarsiantar is considered weak for several reasons, among them is the first, the target audience to receive political messages from the community leaders instead of audiences that have been built and nurtured by community leaders themselves. Second, many community leaders do not maximize the role of communication (inactive) in the community. Third, there is no candidate for mayor who is Muslim and fourth, very strong allegation of money politics practice.

\section{BIBILIORAPHY}

Aubrey Fisher, Small Group Decision Making: Communication and the Group Process. McGraw Hill New York, 1980

Badan Pusat Statistik tahun 2010

Baron and Byrne, Social Psychologi: Uderstanding Human Intraction. Boston: Allyn and Bacon.Inc, 1979

Brend D. Ruben, Communication And Human Behaviour. New Jersey: Prentice Hall, 1992, Cet. 3

Carles Wright dan Murel Cantor, the opinion on Seeker and Advoider. Pacific Sociological Review 10, 1967

Gun Gun Heryanto dan Rumaru Shulhan. Komunikasi Politik Sebuah Pengantar. Bogor: Ghalia Indonesia, 2013 
Ibrahim Mustafa dkk, Al-Mu'jam al-Wasith. Kairo: Dar al-Da'wah

Jalaluddin Rahmat, Etika Komunikasi Perspektif Religi. Jakarta: Perpustakaan

Jimly Asshiddiqie, Komentar atas Undang-Undang Dasar Negara Republik Indonesia Tahun 1945. Jakarta: Sinar Grafika, 2009

John G. Oetzel dan William B. Gudykunst, Effective Intercultural Work Group Communication Theory, in Theorizing About Communication and Culture, ed., Thousand Oaks, CA: Sage, 2005

Marshall Scott Poole, David R. Seibold, dan Robert D. McPhee, "A Communication and Group Decision-Making, ed., Beverly Hills, CA: Sage, 1986

Meriam Budiardjo, Dasar-Dasar Ilmu Politik. Jakarta, Gramedia Pustaka Utama, 2008

Michael B Salwen dan Don W. Stacks, An Integrated Approach to Communication Theory and Research, ed. Mahwah, NJ: Lawrence Erlbaum, 1996

Morissan, teori Komunikasi: Individu Hingga Massa. Jakarta: Kencana, 2014

Musnad Ahmad, Juz 20, Hadis No. 13048. Muassasah al-Risalah, 1421-2001, cet.1

Nawawi Hadari, Penelitian Terpadu. Yogyakarta: Gajah Mada University Press, 1996

si, Theories of Human Communication, Edisi 9. Jakarta: Salemba Humanika, 2008

Stephen W. Littlejhon, Theory of Human Communication, $6^{\text {th }}$ Edittion. California: Wadawort Publishing Company, 1999

Internet

http://news.metro24jam.com/read/2016/11/18/1671/surfenov-tak-penting$\mathrm{pk}, 18$ November 2016 - 03:46 WIB

Daulat Sihombing, adalah Ketua Sumut Watch, yakni sebuah Ornop di Kota Medan yang bergerak dibidang pemantauan dan pengawasan kebijakan publik di Sumatera Utara. http:/ / isiantar.com/surat-terbuka-untuk-mahkamah-agung-ridagelan-pilkada-kota-pematangsiantar/ 06/09/2016 